\title{
Are Local Regulations in Indonesia Compatible with Human Rights?
}

\author{
Martitah \\ Universitas Negeri Semarang \\ Kampus Sekaran, Gedung K, Semarang, Indonesia \\ Corresponding e-mail: \\ martitahlatif@mail.unnes.ac.id
}

\begin{abstract}
In the last few years, the Indonesian government --the Minister of Home Affairs-- has canceled many local regulations. by. This paper aims to examine whether the local regulations abrogated in Indonesia $d$ not uphold the human rights. It is also to show how the local regulations are generally deemed inappropriate for human rights values. The study findings indicate that the government canceled the local regulations for several reasons. First, they can hamper the investment and licensing processes, for example the regulation in Cilacap Regency, Local Regulation No. 12/2011 about Building Permit Levies. Second, they are contrary to the higher regulation, for example Local Regulation No. $18 / 2010$ on Hotel Tax contradicts to Act Number 33/2004 about the Financial Balance of Central and Regional Governments. Third, they are overlapping regulations that disturb public order because local governments unilaterally establish new tax objects. For example, the imposition of a parking tax for valet service in the Buton Regency of Southeast Sulawesi No. 1/2013. Besides the revoked regulations above, there are some local regulations incompatible with the human rights which are still valid. They are mostly sharia-based, for example, Local Regulation of Padang City No. 3/2004 on the Prevention, Eradication, and Prosecution of Social Diseases. Local Regulation in Aceh Province Number 5/2003 on Moeslim Dressing. This regulation violates the rights of the people (human rights) to make their own decisions about what they wear. The study findings imply that in issuing local regulations, the local governments need to consider that Local regulations should be made clearly; should not be contrary to higher regulations; should not violate human rights;should be constant; and should invite the public involvement in the process of rulemaking, and socialization.
\end{abstract}

\section{Keywords-Human Rights; Local Regulation;}

\section{INTRODUCTION}

The existence of local regulations and alleged violation of human rights principles are a classic problem since the New Order era. This is the consequence of the human rights principles adopted in Indonesia. As the people were aware of the importance of human rights values, in issuing regulation the government took it into consideration. However, according to the Minister of Finance of the Republic of Indonesia, in the field of finance there are still many problematic local regulations that have been evaluated and revoked by the government, as presented in the following table.

Table 1.1 Local Regulation Revoked in Indonesia

\begin{tabular}{|c|c|r|}
\hline Year & Evaluate & Revoked \\
\hline 2009 & 14,000 & 1,800 \\
\hline 2010 & 3,000 & 407 \\
\hline 2011 & 9,000 & 351 \\
\hline $2015-$ & - & 1,000 \\
\hline
\end{tabular}

(Minister of Finance of the Republic of Indonesia, 2016).

The government has canceled the local regulations because they are contrary to the higher regulations assessed to inhibit investment. Such number of problematic local regulations indicate that the process of the rulemaking does not consider the parameters of human rights as mandated by the Minister of Law and Human Rights and the Minister of Home Affairs. The process misses

the principles of transparency, accountability and participation which are the essential concept of good governance.

The problematic local regulations both formally and materially raise several issues, among others: first, their implementation does not apply effectively in the community; second, they get rejected from the community because they are considered to be impartial to the community; third, they can impede national development because they do not support efforts create a conducive business and investment environment, and fourth, they can threaten the protection of human rights. Therefore, the problem to be investigated is whether the 
abrogated local regulations in Indonesia do not uphold the human rights.

\section{Principles Of Human Rights In The Establishment OF LOCAL REGULATION IN INDONESIA}

The principles of human rights provide the governments with a set of performance standards to do their duties and jobs accountably. In addition, the principles of human rights also consist of the materials leading to create a good governance, for example, developing legislative frameworks, issuing policies, planning programs, allocating the budget and so on. Without good governance, human rights can not be respected and protected The enforcement of human rights depends on a conducive environment resulted from the establishment of good governance principles.

UN Office of the High Commissioner for Human Rights explains that human rights principles provide a set of values to as a reference to guide and conduct duties for governmental officers, political actors and other social drivers.

According to Rhona KM. Smith, there are three principles of human rights, namely equality, nondiscrimination, and the positive obligations of each country.

Meanwhile, Joint Regulation between the Minister of Justice and Human Rights, and the Minister of Home Affairs Number 20 and 77 of 2012 on Human Rights Parameters in the Establishment of Local Regulation Products, provides various consequences and implications in the establishment of local regulation products, and at the same time becomes parameters in their enforcement to be in harmony with justice in society.

The parameters include (1) non discrimination, (2) gender equality, (3) distribution of governmental affairs pursuant to Government Regulation Number 38/2007 on Division of Government Affairs between the Government, Provincial Government and Regency/City Government, (4) The values of human rights in the provisions of the laws and regulations.

The implementation of human rights relies on a conducive environment which includes appropriate legal frameworks and institutions as well as political, managerial and administrative processes responsible for responding to the rights and needs of the population (Saikia, Ishan. 2013).

The principles of human rights is closely linked to good governance. In administrative law, The European Union state members have organized various academic activities discussing the principles of good governance in relation to European administrative law. The study of administrative law concerning the functions and approaches to administrative law clearly indicates the use of ruling power regarding the behavior of the apparatus in performing services to the public. The use of ruling power rests on the principle of legality (Haris, Oheo K. 2015, p.79).
When further explored, a good governance has several patterns to strengthen the protection of human rights, which encourages the involvement of the public largely in the government, especially the groups that need to be protected (minority), both in the formation of the rule of law and the preparation of various Policy. Such a pattern ensures that every legislation and policy adopted applies the principles of accountability, transparency, and participation of community (Addink, 2010).

The establishment of an ideal rule of law implies that the process of formulating rules of law should be based on the principles of good governance that guarantees the protection of human rights. This shows, there is a close relationship between the product of local regulation and human rights. The relationship is in the form of accommodating all the interests of society widely based on the values of human rights, whether derived from the ideology of the nation, legislation and international law. One way to achieve this is to apply the principles of good governance in the formation of local regulation products.

The appearance of problematic local regulations both formally and materially raises several issues, among others: first, their implementation does not apply effectively to the community; second, they get rejected from the community because they are considered to be impartial; third, they can hamper national development because they do not support efforts to create a conducive business and investment climate, and fourth, the most important one, they can threaten the protection of human rights. If traced, the failure of legislation in Indonesia could be caused by inadequate scientific studies. Furthermore, the low quality of legal drafter, lack of facilities and infrastructure and inadequate political configuration contributed to the high number of poor quality regulations.

\section{RESEARCH METHOD}

This study is a doctrinal research. According to Terry Hutchinson (2002), doctrinal research is a research which provides a systematic exposition of the rules goverming a particular legal category; analyses the relationship between rules; explains areas of difficulty; and perharps, predicts future development. Doctrinal research asks what the law is on a particular issue. It is concerned with analysis of the legal doctrine and how it has been developed and applied. This type of research is also known as a pure theoretical research. It consists of either a simple research directed at finding a specific statement of the law or a more complex and in depth analysis of legal reasoning (McConville and Wing, 2007).

\section{STUdy Of LOCAL Regulation Formed Not Through PRINCIPLES OF HUMAN RIGHTS}

At the beginning, it was mentioned that the government had canceled 3,143 local regulations in 2016. The canceled local regulations can be differentiated into 12 groups, among others; (1) local regulations about tax and retribution; (2) 
minerals, gas, mining and coal; (3) population administration; (4) management of local assets; (5) agriculture and plantation; (6) water resources and irrigation; (7) local government-owned enterprises; (8) licensing; (9) management of provincial and district/city government affairs; (10) management of education, Indonesian workers and child rights; (11) services; and (12) electricity management. Of these groups largely a local regulation on retribution, taxes and administrative management dominated, whereas the least was about local regulation on HIV and morality.

In Cilacap Regency, Central Java, several local regulations on retribution are usually packaged in a sustainable and interdependent levies, such as building permit levies (Local Regulation No. 12/ 2011), disturbance permit (Local Regulation No. 16/2012) and certain licensing cost. In fact, retribution of building permits is a part of a certain licensing levy. However, to increase the local autonomy's local revenue, both types of retributions are differentiated. This means, when someone wants to establish a Hotel completed with restaurant and entertainment facilities, he must spend a very high cost for levy besides paying taxes, among others: Local Regulation No. 18/2010 on Hotel Tax, Local Regulation No. 18/2010 on Tax Entertainment and Local Regulation No. 18/2010 on Restaurant Tax.

These local regulations on levies contradict Law Number 33/2004 about the Financial Balance of Central and Regional Governments. Changes in the amount of levies, including taxes inhibit investment, and make the costs high. This contradiction disrupts the people's economic activities and hinders their mobility. Even Feldstein (2008) considers that changes in tax rates affect the behavior of taxpayers as consumers, and the amount of taxable consumption (including home ownership, charitable contributions, and local property taxes).

Meanwhile, the revoked tax regulation is dealt morewith tax subjects which in turn slows the regional economic growth. Regional taxes should not be enforced on tax objects that have high mobility, but be directed to low-mobility objects such as properties, lights and buildings, banners/billboard, hotels, and restaurants. This also ensures the freedom of movement of goods and services. Most of the revoked tax regulations are motivated by the overlapping regulations and disturbing public order because local governments unilaterally establish new tax objects. For example, the imposition of a parking tax for valet service in the Buton regency of Southeast Sulawesi ruled by regulation No. $1 / 2013$ and the imposition of a restaurant tax for a bakery in the Balikpapan ruled by regulation Number $15 / 2010$ should be the authority of the central government. If not canceled, it can hinder investment. A study done by Philippe Aghion, etc. (2016) revealed that taxation reduces the reward for entrepreneurial innovation and therefore discourages investments that are important for the economic growth.

The content of local regulation on the occupation administration is very detrimental to the society. Almost every region has this regulation, which is related to the printing cost of the Identity Card, Family Card and other civil registration certificate. Actually, the Indonesian government through the Ministry of Home Affairs has budgeted a very large fund for the issuance of certificates of civil registration to eliminate any charge and fee. This is the juridical consequence of the Decision of Constitutional Court Number 46/PUU-XII/2014 stating that the levy on the printing of identity cards and any civil registration certificate contradicts Law No. 24/ 2013 on Population Administration (Martitah, 2013).

In the Central Java Province, most of the regulation stipulates a levy for the cost of printing a population administration certificate (10 districts/ cities), among others are the Local Regulation of Pekalongan City Number 14/2011, Local Regulation of Wonosobo Regency Number $7 / 2009$, Local Regulation of Temanggung Regency Number $7 / 2012$, Local Regulation of Sragen Regency Number $7 / 2006$, Local Regulation of Rembang Regency Number 6/2008, Local Regulation of Jepara Regency Number 7/2010, Local Regulation of Cilacap Regency Number 10/2013, Local Regulation of Brebes Regency Number 2/2009, Local Regulation of Banyumas Regency Number 6/2009 and Local Regulation of Banjarnegara regency Number 2/2009.

Besides the revoked regulations above, there are some local regulations that incompatible with the human rights and have not been canceled by the government. The formalization of Islamic sharia into the content of the local regulation is not only inconsistent with the principles of Indonesia's democratic system but is also considered inconsistent with the principles of human rights. The content material sourced from Islam sharia only refers to the point of view of one religion, Islam, this contradicts the principle of equality and non-discrimination. It has been implied in the concept of human rights, but not in written legislation as well as in local regulations. The content based on Islamic Sharia contains elements of discrimination that are less favorable to individual directly or indirectly. The direct impact can be what a person feels from the rule of law; and the indirect impact can be a form of discrimination arises in its practical level. .

There are many Islamic Sharia perspective-based local regulations that apply in Indonesia for example, Local Regulation of Padang City No. 3/2004 on the Prevention, Eradication, and Prosecution of Society Diseases. The regulation states that "Every woman is prohibited from wearing clothes that can stimulate the passion of men who happen to see her in a public place, except at places considered private." This could potentially lead to violate human rights because it restricts the freedom of expression in the public sphere in the form of dress. The restriction is a kind of violation of individual rights. Local Regulation of Aceh Province Number 5/2003 about Dressing Moeslim violates the right of the people (human rights) to make their own decisions about what they wear.

Local Regulation of Banten No. 8/2005 on Prohibition of Prostitution. The material content of this rule imposes a curfew for a woman. This will potentially lead to abuse and do arbitrary acts because of the unclear criteria that distinguish between a woman who works at night and a 
woman who prostitutes herself. Therefore, its implementation raises the potential for human rights violation.

\section{CONCLUSION}

The appearance of problematic local regulations raise several issues, among others: their implementation do not apply effectively in the community; they get rejected from the community because they are considered to be impartial to the community; they can hinder the national development, investment and licensing, and; contrary with higher rules. There are several local regulations in Indonesia incompatible with the principles of human rights, especially those are based on Islamic sharia perspective, and have not been canceled by the government.

The study findings imply that in issuing local regulations, the local governments need to consider that Local regulations: (1) should be made clearly; (2) should be rational; (3) should not be contrary to higher regulations; (4) should not violate human rights; (5) should be constant; and (6) should invite the public involvement in the process of rulemaking, and (7) socialization.

\section{REFERENCES}

[1] Addink, Henk. (2010). Human Rights \&Good Governance, SIM Special 34, (Antoine Buyse \& Cees Flinterman Edited by Henk Addink, Gordon Anthony ed). Netherland: Utrecht University.

[2] Alm, J., R. H. Aten and R. Bahl. (2001). Can Indonesia Decentralise Successfully? Plans, Problems and Prospects, Bulletin of Indonesian Economic Studies 37 (1).
[3] Bell, G. F. (2001). The New Indonesian Laws Relating to Local Autonomy: Good Intentions, Confusing Laws, Asian-Pacific Law \& Policy Journal 2(1).

[4] Feldstein, Martin. (2008). Effects of Taxes on Economic Behavior. National Tax Journal 61(1): 131-139.

[5] Haris, Oheo K. (2015). Good Governance (Tata kelola Pemerinrtahan Yang Baik) Dalam Pemberian Izin Oleh Pemerintah Daerah Di Bidang Pertambangan, Jurnal Yuridika, Volume 30 Nomor 1 Januari 2015. Surabaya: Fakultas Hukum Universitas Airlangga.

[6] Hutchinson, Terry. (2002). Researching and Writing in Law. Sydney: Lawbook. Co.

[7] Juwana, Hikmahanto (2006) 'Human Rights in Indonesia'. In Randall Peerenboom et.al. (eds), Human Rights in Asia: A Comparative Legal Study of 12 Asians Jurisdictions, France, and the USA, New York: Routledge

[8] Lewis, Blane D. (2003). Tax and Charge Creation by Regional Governments Under Fiscal Decentralization: Estimates and Explanations. Bulletin of Indonesian Economic Studies 39 (2).

[9] Martitah. (2013). Mahkamah Konstitusi dari Negative Legislature ke Positive Legislature. Jakarta: Konstitusi Press.

[10] McConville, Mike and Wing Hong Chui, eds. (2007). Research Methods for Law. Edinburgh: Edinburgh University Press.

[11] Parsons, Nicholas and Marcus Mietzner. (2010). Sharia By-Laws in Indonesia: A Legal and Political Analysis. Australian Journal of Asian Laws II, 2.

[12] Ramage, Douglas. (2007). Indonesia: Democracy First, Good Governance Later. in Daljit Singh and Lorraine C. Salazar, eds. Southeast Asian Affairs. Singapore :Institute of Southeast Asian Studies.

[13] Saikia, Ishan. (2013). Good Governance and Human Rights: International and National Perspective. International Journal of Advancements in Research \& Technology, 2 (7), 124- 134. Retrieved from http://www.ijoart.org/ docs/good-governance-and-humanrights- international-and-nationalperspective.pdf

[14] Smith, Rhona MK. dkk., Hukum Hak Asasi dalam Mujaid Kumkelo, dkk., (2008). Fiqh HAM, Yogyakarta: Pusham UII. 